\title{
The Role of Takwin AL-DU'AT in Developing Professional DA'I: An Investigation from Tafsir Al-Manar
}

\author{
Azizul Azra Bin Abdul Razak \& Mohd Hisyam Bin Abdul Rahim \\ ${ }^{1}$ Department of Islamic Studies, General Education Centers and Co-Curiculum, Tun Hussein \\ Onn University, Malaysia \\ ${ }^{2}$ Department of Islamic Studies, General Educarion Centers and Co-Curiculum Tun Hussein \\ Onn University, Malaysia
}

DOI - http://doi.org/10.37502/IJSMR.2021.4706

\begin{abstract}
Preachers in the Islamic sense are implementors for the purpose of amr ma'ruf nahy munkar. The main requirement for a preacher is to develop the personality as a da'i (takwin al-du'at) before he commits himself in dakwah activities professionally. However, in the Malaysian context, there is a lack of clarity regarding the development of the da'i personality especially from the analysis of the Quran. As such, this study aimed to focus on the development of the dai personality and to analyse the takwin al-du'at concept as written by Muhammad Abduh in his work, tafsir al-Manar. This study was conducted using library research by applying the data and content analysis method to achieve the research aims. The findings had identified a few important aspects in understanding how to develop the da'i personality according to the Quran. The study implication provided clear understanding on developing the da'i personality which should be further improved as an enhanced mechanism in the context of current dakwah situation.
\end{abstract}

Keywords: Personality, Dakwah, Da'I, Takwin al-Du'at.

\section{Introduction}

Generally, Dakwah is the activity of preaching to others towards doing good, which is according to fitrah, or what Allah has bestowed to humankind, by focusing solely on Allah swt and practising good deeds and abstaining oneself from doing evil acts as decreed.

However, the human being is often exposed to various influences such as worldly temptation and desires which drive them towards commi1989ing acts which go against mankind's original fitrah.

Additionally, there are some individuals who have an honourable nature and have the potential to become professional da'i with the role of implementing dakwah activities. They call upon other individuals to return to their fitrah or their original, uncorrupted nature. As such, the terms takwin al-du'at or tabiyah al-du'at are used to realise the compulsory requirement of dakwah (amar takwin) or the requirement for the development of dakwah preachers who are trained, knowledgeable and competent to fulfill the requirements of a professional Islamic preacher.

\section{Literature Review}


The grand agenda of dakwah is to call upon people to devote themselves totally to Allah History has shown that the community depends on the concerted efforts of the ulama, who is usually an outsider, to spread the Islamic faith. As such, for the purpose of strengthening the dakwah effort, there should be preachers who continue the effort of propagating the faith in a professional manner. The ulama's main efforts in helping to produce professional $d a$ ' $i$ could be seen in the formation of the Islamic institutions of higher learning and the publications of Islamic works (Mohd. Fadli Ghani: 2018). Some of the ulama who had focused on the dakwah islah concept via the recruitment and training of professional $d a$ ' $i$ included Muhammad Abduh and a few others who had the same vision.

Ahmad Fuad al-Ahwani (1965) described in 'al-Madaris al-Falasifah', that Muhammad Abduh was a thinker who introduced a new way of religious thinking with a return to authentic Islam through the main sources of al-Quran and al-hadith, in the form of islah (transformation, innovation, reformation) of religious life, behaviour, thinking, mindset and such.

Abd al-Badi' al-Shaqar (1976) in his work 'Kayfa Nad'u al-Nas', stated the same element regarding the main aspect in the effort towards islah al-da'wah via the recruitment or training of the professional $d a^{\prime} i$. According to him, the professional $d a^{\prime} i$ is a learned Muslim who has made dakwah as his career based on his membership as a dai, which is based on the mastery of Islamic knowledge and the Islamic way of life as a dakwah practice.

A. Mukti Ali (1995) in 'Alam Pemikiran Islam Modern di Timur Tengah', among others, explained that the methods of thinking and translating of the Quran by Muhammad Abduh was by combining the rational (the intellectual aspect) and the emotional (the emotional aspect) in a dakwah framework. This shows the focus on the individual's internal aspect before he is transformed into a professional $d a$ ' $i$.

The dakwah thinking of Muhammad Abduh in the al-Manar tafsir was exemplified in a dissertation by Syukriadi Sambas (2009). It described that dakwah according to Abduh was categorised into two parts: dakwah towards the non-Muslim (tabligh futuhat) and dakwah to the general public (al-da'wah al-ammah al-kulliyah). Additionally, Abduh also proposed a few transformations in Islam in the form of amr ma'ruf nahy munkar which were similar with the one proposed by thinkers such Ibn Taimiyah and Abdul Karim Zaidan, who described them as al-hisbah and al-ihtisab.

Previous studies showed that the dakwah thinking of Muhammad Abduh focused on his tafsir 'Al-Manar' which was related to the study of specific dakwah in training professional Islamic preachers. The findings showed that the data could be acquired in the form of primary or secondary data and it could then be analysed in a descriptive manner.

\section{Study Methodology}

This is a qualitative study which involved library research. The data collection methods utilised were the analysis of case content, articles, books and discourse. As for the data analysis, this involved descriptive analysis suitable with the study objective which was defining the terms takwin al-du'at or tabiyah al-du'at in the effort to develop dakwah implementors $\left(d a^{\prime} i\right)$ who are knowledgeable, skilled and trained to fulfill the characteristics of professional dakwah preachers. 


\section{Analysis and Discussion}

\section{1: Takwin al-Du'at}

The terms takwin al-du'at or tabiyah al-du'at are utilised to realise the compulsory requirement of dakwah (amar takwin) or the compulsory requirement for the formation of dakwah implementors $\left(d a^{\prime} i\right)$ who are trained, knowledgeable and skilled in order to fulfill the characteristics of the professional dakwah preachers. This has been mentioned by Muhammad Abduh as khawash al-ummah (the chosen individual with the duties of the $d a$ ' $i$ ) (Muhammad Abduh: 1989).

As such, takwin al-du'at could be interpreted as the effort to prepare the $d a{ }^{\prime} i$ candidates with knowledge in the theoretical and practical aspects related to Islamic dakwah as the community component with knowledge in the processes of ta'lim (knowledge transmission), tadris (intensive learning), tafaqquh (in-depth understanding), tazwid (provision of membership) and tadbir (personality management) . (Syukriadi Sambas: 2009)

Muhammad Abduh realised the importance of having professional da'i in this modern age. One of his reasons for this was related with his criticism of a group of undergraduates who had started to neglect the values of the preservation of life (nafs) and the struggle to revitalise Islam. (Muhammad Abduh: 1989)

\section{2: Requirement in Preparing the Professional Da'i (Takwin al-Du'at)}

Muhammad Abduh was confident that the implementation of dakwah would continue when the cadre of $d a^{\prime} i$ were able to carry on with the previous $d a$ ' $i$ duties constantly. As such, Abduh explained using the translation of surah al-Taubah, verse 122 about the importance of having professional da'i before the process of tafaquh fi al-din. As stated in the mentioned verse:

"And the believers should not all go out to fight. Of every troop of them, a party only should go forth, that they (who are left behind) may gain sound knowledge in religion, and that they may warn their folk when they return to them, so that they may beware."

According to Muhammad Abduh, this verse describes the division of duties in the structure of khayr ummah. This means that the task division is not equal due to other needs and as such, takwin $\boldsymbol{d a} \boldsymbol{i}$ in the profesional sense functions to develop a continuous dakwah chain. As stated by Abduh, the expressions liyunzira and yahzarun pertain to some activities in Islamic dakwah (Muhammad Abduh: 1989)

Abdullah Syahatah (1978) further added a few aspects required in the provision of professional $d a$ ' $i$ training.

i. The da'i should be able to understand and utilise the modern mass media to disseminate advice about dakwah (the task to provide modern information technology facilities)

ii. Building Islamic dakwah centres to supervise the training of the cadre of professional da'i (facilities/infrastructure for training centre)

iii. Preparation in deploying profesional da'i resource globally with adequate facilities and transport (dakwah logistics) 
iv. Preparation of infrastructure and funds required to ensure smooth dakwah operation by the cadre of professional $d a^{\prime} i$.

v. The trained $d a{ }^{\prime} i$ should create and develop a conducive environment for the process of teaching Islamic values to the mad'u.

Additionally, Fathi Yakan (1983) added that the cadre of professional $d a$ ' $i$ should prepare the qualified da'i with these characteristics:

i. Having in-depth Islamic knowledge with mastery of required skills

ii. Showing good conduct and example (uswatul hasanah).

iii. Having mental strength and resilience in conducting tasks

iv. Having social solidarity with other $d a^{\prime} i$.

v. Showing a generous nature towards others

vi. Having an honourable a1989itude towards others

vii. Showing a good and a1989ractive personality in public presentations

viii. Able to handle the delivery of teaching materials

ix. Having the ability to withstand the various behaviours of the mad'u.

As such, the implementation of the takwin al-du'at is important in order to train the professional dai in line with the stipulated guidelines so that the requirements of a professional dai could be fulfilled adequately

\section{3: The Basis for Takwin al-Du'at}

The discussion concerning the requirement for the implementation of takwin al-du'at is based on Allah's decree as the following:

"Let there be a group among you who call 'others" to goodness, encourage what is good, and forbid what is evil-it is they who will be successful".

Muhammad Abduh (1989) asserted that this order of dakwah (according to the manthuq viewpoint, in which the meaning is based on the spoken le1989ers) is directed towards the ummah and khayr ummah, meaning that the effort towards preparing the individual to become professional $d a{ }^{\prime} i$ is an obligation for the dakwah implementors themselves.

In this aspect, Abduh clarified his opinion regarding the basis and purpose for takwin $a l-d u$ 'at, as the obligation for every Muslim to call others to do good and to deter others from doing evil (amr ma'ruf nahy munkar) is aligned with the the first call in that particular verse. As for the second call, it refers to the selection of a group of individuals who would carry out the dakwah obligation in a specific and professional manner and they themselves are able to implement the responsibility.

Muhammad Abduh (1989) also stated that a professional member is a person with academic knowledge and his ability to implement tasks is based on the qualification that he owns. In this current context, the Department of Dakwah and Leadership in the Faculty of 
Islamic Studies, Universiti Kebangsaan Malaysia plays a huge role in transforming the nation's dakwah modernisation pa1989ern using its expertise.

\section{4: The Purpose of Takwin al-Du'at}

Regarding the takwin al-du'at, Muhammad Abduh referred to Surah Ali Imran verse 79, which could be translated as such:

"It is not for a human [prophet] that Allah should give him the Scripture and authority and prophethood and then he would say to the people, "Be servants to me rather than Allah," but [instead, he would say], "Be pious scholars of the Lord because of what you have taught of the Scripture and because of what you have studied."

Muhammad Abduh explained that the prophets had been blessed with the scriptures and they were called upon to learn and later teach the contents to other members of society. This was because the knowledge in the scriptures which was disseminated and practised created a closeness between mankind and the Creator. The scriptures were a mediator in the process of making one closer to Allah s.w.t and the prophets were an intermediary which helped to disseminate the scriptures (Muhammad Abduh: 1989)

From the explanation given by Abduh above, it could be understood that the purpose of takwin al-du'at is to develop a cadre of dai who can function as umat rabbani or a religious community which masters knowledge and practises it. Their tasks are to continue the dakwah obligation by emulating the good deeds shown by the prophets as dai and the preachers with their various functions. This could be seen in surah al-Ahzab, verses 45-46, where Allah's prophets and messengers carried the responsibilities as syahid (witness), mubasyir (bearer of good news), nadzir (a person who warns), $d a^{\prime} i$ (one who calls upon others) and siraj munir (the illuminating light).

Muhammad Abduh also described that the conduct of the takwin al-du'at would pertain to al-muallim (teacher) who possesses in-depth knowledge of the takwin theory and practises the knowledge. Additionally, the knowledge which is not practised would not be considered as true knowledge, as true knowledge is knowledge that is characteristic of its owner and becomes part of oneself. One's deeds act as a reflection of one's characteristics and features. A learned person would be evaluated from what could be seen from what has surfaced from the knowledge that he possesses (Muhammad Abduh: 1989)

The takwin al-du'at method also refers to the sunnah (practices) of Nabi s.a.w. in teaching the society at that time. The Prophet's experience in receiving the revelation is an inspirational source of the takwin al-du'at method. As such, Muhammad Abduh opined that in the translation of surah al-Dhuha, verses 6-8, the issue concerned was the main principles in developing takwin al-du'at in brief as the following: (Muhammad Abduh: 1989))

Firstly, the principles of al-iwa al-qawi (solid protection) which are sourced from the decision-making process based on fatwa, refer to the provision of protection to the takwin al$d u$ 'at participants through the spirit of tauhid and aqidah, providing motivation to uphold the truth, strong and fearless in overcoming challenges in dakwah and its enemies, able to control one's nafs ammarah (the part of our soul which incites us to do evil) and to overcome al wahn which is one's desire of worldly things and fear of death. 
Secondly, the principles of al-tarbiyah al-ilmiah (academic education) which are based on $f a$ hada, refer to the process of providing guidance, aid and supplies in mastering academic education, guidance in personality-building via tasks and assignments, the implementation of forms of dakwah methods, which are all conducted by sincere and dedicated muallim (teachers) for the purpose of jihad fi sabilillah.

Thirdly, the principles of al-yusr al-madi (facilties and logistics) which are based on fa aghna, refer to the assistance and the provision of facilities of takwin al-du'at, so that the participants of takwin al-du'at would not be plagued with financial issues and such during their training. The financial aid could be acquired from resources which are aligned with Islamic principles.

Fourthly, the principles of al-tadrij (gradually) involve the process of disseminating the dakwah theories gradually from the simple topics to more complex topics, the need to acquire knowledge in aqidah before syariah knowledge and also the need to observe the capabilities of the takwin al-du'at participants. These principles are based on the translation of surah al-Baqarah, verse 151 (Muhammad Abduh: 1989)

As such, if takwin al-du'at could be implemented properly, then the dakwah activities could be conducted according to the principles outlined in the Quran and the Prophet's sunnah practices. Additionally, the problems of the ummah could be alleviated with the assistance of these $d a$ ' $i$. If it fails, then it could probably contribute towards a problematic and disastrous situation in the Muslim community (Muhammad Abd al-Masri: 1989)

\section{Conclusion}

Based on the discussion above, it could be concluded that the quality of dakwah implementation requires a $d a^{\prime} i$ who is properly qualified and trained. This means that it is a requirement for the $d a ' i$ to undergo takwin al-du'at (preparation to become a preacher) so that he could be included in a select group of professional $d a{ }^{\prime} i$ who have mastered various aspects such as knowledge, a dynamic preacher personality as well as other principles which should be inculcated by taking the inspiration from the revelation which had been revealed to Rasulullah s.a.w as guidance throughout the ages.

\section{Acknowledgements}

All Praises to Allah and His blessing for the completion of this article. I would like to sincerely thank my supervisor Dr. Mohd. Hisyam Abdul Rahim for his guidance, understanding, patience and most importantly, he has provided positive encouragement and a warm spirit to finish this article. I offer my special thanks to all my family members, colleagues, teachers and friends. May God shower the above cite personalities with success and honour in their life.

\section{References}

1) A. Mukti Ali (1995), Alam Pemikiran Islam Modern di Timur Tengah, Jambatan, Jakarta.

2) Abd Allah Syahatah (1978), Al-Da'wah al-islamiyah wa al-Ilam al-Dini, al-Hayiah alMishriyah al-Ammah li al-Kitab, Kaherah.

3) Abd. al-Badi' al-Shaqar (1976), Kayfa Nad'u al-Nas, Maktabah Wahbah. Kaherah. 
4) Ahmad Fuad Ahwani (1965), Al-Madaris al-Falsafiyyah, Maktabah Mesir, Kaherah.

5) Bambang Saeful, 1989. Bencana di Dunia Islam, terj. Muhammad Abd al-Masri, Karitsah fi al-Alam al-Islami, Rosdakarya, Bandung.

6) Fathi Yakan (1983), Al-Islam, Fikrah -Harakah-Inqilab, Muassasah al-Risalah, Beirut.

7) Mohd. Fadli Ghani (2018), Ulama dan Pembentukan Keder dakwah. aktikel 22/6, harakahdaily.net.

8) Muhammad Abduh, (1989), Tafsir al-Manar, Dar al-Fikr, Beirut.

9) Syukriadi Sambas (2009), Pemikiran Dakwah Muhammad Abduh dalam Tafsir alManar, Disertasi Doktor Falsafah Ilmu Agama Islam, Universitas Islam Negeri (UIN) Syarif Hidayatullah, Jakarta. 